\title{
Social Minds and Narrative Time: Collective Experience in Thucydides and Heliodorus ${ }^{1}$
}

Jonas Grethlein ${ }^{1}$

It has become clear only in recent years to what extent narratology can benefit from historical analysis. A synchronic focus is part of the discipline's structuralist inheritance and has been readily adopted by some of the new narratologies that emerged in the last two decades. However, narrative forms and functions change over time. It is worth inquiring into the history of such narrative features as focalization, description and metalepsis as well as into the metamorphoses of genres. Monika Fludernik's programmatic investigation of scene shifts provides a splendid example ("Diachronization"). In Middle English prose and verse narrative, a shift of scene is frequently introduced by such formula as "we now leave $\mathrm{X}$ and $\mathrm{Y}$ and turn to A and B, who were..." Such markers were made superfluous by the introduction of chapters. They nonetheless survived and can still be found in the modern novel, albeit with a new function: here, the metalepsis is used for ironic and parodic purposes. What was originally a structuring device has become an instrument of metafictional play.

Historical analysis not only alerts us to the transformations narrative features undergo, it can also help us reconsider the theory of narrative. In this essay, I shall deploy ancient narrative to highlight a lopsidedness in current narrative theory. My argument is not so much a critique of cognitive approaches as an attempt to complement them. Alan Palmer's work on fictional and especially social minds is emblematic of a broader trend to consider "theory of mind" the key to our response to narrative. While Palmer defines narrative as "the description of fictional mental functioning" (Fictional Minds 12), Lisa Zunshine argues that "certain

\footnotetext{
${ }^{1}$ Jonas Grethlein holds the Chair in Greek literature at Heidelberg University and currently directs the research group "Experience and teleology in ancient narrative" funded by the European Research Council. His recent publications include Littells Orestie: Mythos, Macht und Moral in "Les Bienveillantes" (Freiburg 2009), The Greeks and their Past (Cambridge 2010) and Experience and Teleology in Ancient Historiography (Cambridge 2013). He can be reached at jonas.grethlein@skph.uni-heidelberg.de.
} 
cultural artifacts, such as novels, test the functioning of our cognitive adaptations for mindreading while keeping us pleasantly aware that the 'test' is proceeding quite smoothly" (18). The primary use of narrative seems to consist in offering us a training camp for "theory of mind." In the eyes of many cognitive narratologists, mind-reading is at the core of our response to narrative.

There can be no doubt that coming to grips with social minds as well as with fictional minds more generally is a salient aspect of the reading process. Social minds also permeate ancient narrative. As my examples will illustrate, ancient authors deploy internal focalization with great efficiency and draw on a large arsenal of devices for subtle shifts of perspective. And yet even in the ancient novel the presentation of characters and their minds is less an end in itself than a means to render an action in a vivid way. The definition of narrative as the description of processes of consciousness may work well for some classical modern novel which scholars like Palmer concentrate on; it does not hold true, though, for ancient narrative. ${ }^{2}$ Ancient novels as well as ancient historiography and epic draw our attention to another aspect that is, I think, equally important, namely time. Narrative time has received much attention in the Neo-Aristotelian and phenomenological traditions. ${ }^{3}$ In cognitive studies, however, while not completely ignored, narrative time does not have the place it ought to have. My exploration of collective experience in ancient Greek narrative will illustrate that the cognitive dynamics of narrative can be fully understood only if we take into account the entwinement of social minds and fictional minds in general with narrative time.

I will discuss two exemplary scenes featuring collective experience, one from historiography (Thucydides), the other from an ancient novel (Heliodorus). Other than public manifestations, collective experience encompasses emotions and thoughts that are shared by a group but hidden in their minds. For Dorrit Cohn, the access to such mental processes sets fiction apart from factual texts (16-17). While the historian is confined to the evidence of his 
sources, the novelist is at liberty to delve into the interior lives of her characters. In ancient literature, however, this division does not work. Greek and Roman historians are not shy of elaborating on the interior processes of historical agents. ${ }^{4}$ Even Thucydides, hailed as the father of critical historiography, roams without further ado through the minds of Pericles, Nicias and Brasidas. There is, I daresay, little, if any, difference in the presentation of fictional minds between ancient historiography and the novel. ${ }^{5}$

Instead of elaborating on this observation, obvious for anyone familiar with ancient literature, I will try to show that in both genres the representation of collective experience is an important device to entice the reader. Thucydides's famous account of the Syracusan harbor battle is a case in point. I will argue that the explicit presentation of the battle as a collective experience is bolstered by more subtle markers such as tense and style (I). Turning to the ancient novel, we can make similar observations. My test-case will be a scene from Heliodorus' Aithiopica, the Delphian foot-race, which receives much of its vividness from an internal audience. Heliodorus allows for subtle differentiations within the crowd of spectators. His account also drives home that the reader's response does not necessarily map directly onto the response of the embedded audience (II). Instead of being an end in itself, the presentation of social minds in both Thucydides and Heliodorus feeds into the temporal dynamics that render narrative experiential. In a final step, I shall tease out some of the ramifications of this observation for cognitive approaches to narrative (III).

\section{Thucydides: Witnessing the Syracusan harbor battle}

Let us start with the account of the Syracusan harbor battle given by Thucydides in book 7 of his History of the Peloponnesian War. ${ }^{6}$ In 415 BCE, the Athenians send a large fleet to Syracuse. The siege, however, does not run smoothly and takes a heavy toll on the army. In 413, the Athenians find themselves in the harbor of Syracuse encircled by the enemy 
army and navy. Trying to break the blockage, 110 Athenian ships face 76 Syracusan ships. The defeat in this battle seals the failure of the Sicilian campaign which at least in the eyes of Thucydides ultimately leads to Athens's downfall in 404.

Along run-up underscores the significance of the sea-battle: Thucydides compares Athens with Syracuse, gives a catalogue of the allies, describes the preparations and recounts several speeches held by generals on both sides. Only then comes the sea-battle: the first half of the report seems to be a straight account of the military maneuvering. The second half, only slightly shorter than the first, concentrates on the soldiers who follow the fighting from land. Before discussing Thucydides's description of the bystanders and their response, an obvious case of collective experience, I shall argue that already the first half of the report intimates the perspective of the soldiers fighting. It seems to be the objective report of the narrator, ${ }^{7}$ but tense, content, and style evoke the vantage-point of an eyewitness.

Let us take a look at the beginning: "When the Athenians drew close to the barrier, they sailed against it and in their first charge overpowered the ships stationed next to it and tried to break the chains; but after this, when the Syracusans and their allies bore down on them from all directions, the sea battle was no longer fought only by the barrier but throughout the harbor ..." (7.70.2): ${ }^{8}$ The use of the imperfect in this and other sentences is noteworthy. Ancient Greek has two main past tenses, besides the imperfect, the aorist. If we follow the account of standard grammars, the difference corresponds roughly to that between passé composé and imparfait in French: while the aorist is punctual and signifies closed events, the imperfect is durative and thus lends itself to describing the backdrop of actions. The imperfect, however, can also be used for the narration of action. In this case it has the capacity to render the account highly mimetic. Being durative, the imperfect presents an activity as ongoing and thus puts the reader into the shoes of an eyewitness who is following the scene as it is progressing. ${ }^{9}$ It has been noted that Thucydides in particular is fond of using 
the imperfect in this way, thereby endowing his narrative with vividness (Bakker, "Verbal Aspect"). ${ }^{10}$

The deployment of the imperfect in the narration of the activities of the Athenians and their opponents in the Syracusan harbor helps to cast the action as a collective experience. By presenting the action not as closed, but as ongoing, Thucydides takes the stance of an eyewitness. Since no individual vantage-point is singled out, it is natural to identify the “displaced immediacy" generated by the imperfect with the vantage-point of the crowd present, notably the soldiers fighting on the ships: before explicitly reporting the view of the land forces in the next paragraph, Thucydides gives us implicitly the perspective of the soldiers fighting on the ships.

Of course, not every imperfect conveys the vantage-point of an eyewitness. That this is, however, the case in our text is suggested by its content and the style in which it is expressed. In the venerable Cambridge Ancient History, Ferguson complains that Thucydides "fails even to suggest the factors that determined the outcome. Instead, he dwells on certain typical incidents in the confused fighting that followed ..." (308). We learn little indeed about the course of the fighting, but this is less a failure on the side of Thucydides than his attempt to represent the experience of the participants in the battle. ${ }^{11}$ Thucydides hauntingly describes the jumble emerging from the meeting of nearly 200 ships in the narrow space of the harbor. Intentional attacks are nearly impossible, ships bump arbitrarily into each other, simultaneously attacking and being attacked. The chaos described by Thucydides is what the soldiers standing on the ships perceive.

Not only the content of the account, also its stylistic presentation adumbrates the perspective of an eyewitness. The repeated use of the copula gignesthai (six times in the first half of the battle account!) drives home that the possibility of action was limited for the combatants: in the narrowness of the harbor, the battle just "happened." The avoidance of 
finite verb forms and the dominance of nouns render the report highly graphic. The following sentence is particularly noteworthy: "It so happened (xunetynchane) that, because of the restricted space, in many places ships had rammed (embeblekenai) others but were rammed (embeblesthai) themselves, so, around one ship, two, in some places even more, were fused together (xunertesthai), and it fell (periestanai) to the helmsmen to ward off some while aiming at others, not one at a time but many and from all over, and the great din from many ships colliding caused consternation and at the same time inability to hear the voices of the coxswains" (7.70.6).

Here it is not gignesthai, but xyntynchanein which expresses the automatism of the battle. The infinitives depending on the impersonal xunetynchane are in perfect tense. In ancient Greek, the perfect mostly has present meaning, marking "the enduring result rather than the completed act" (Smyth 434). While this choice of tense helps freeze the sequential action into one scene, the staccato of the prose renders the confusion felt by the participants tangible: the series of short clauses juxtaposed in sharp antithesis linguistically mimics the disarray of the scene as perceived by the soldiers. Of course, Thucydides surveys the battle as no one present could have done, and yet his account is experiential. As we have sees, the style as well as the content of the description is tailored to express the chaos to which the fighting soldiers are exposed. In presenting the action as durative and unfinished, the imperfect forms contribute to recounting the course of events as it is perceived by the agents.

While the first half of the battle account casts the action as a collective experience implicitly, the second half explicitly describes the response of the bystanders:

And on the shore, as long as the sea battle stayed evenly balanced, the land forces on both sides experienced intense struggles and conflict in their minds, the local army passionately wanting still more glory, the invaders fearing that they would be even worse off than they were now. And for the very reason 
that the fate of the Athenians depended entirely on their ships, their fear of the outcome was beyond anything, and because there was no consistency in their alignment, they were also compelled to view the sea battle without consistency. For since the spectacle was a short distance away, and all were not observing the same thing at the same time, any who saw their own men prevailing would take heart and turn to appeals to the gods that they not be deprived of their salvation; but those witnessing defeat would let out cries of lamentation, and by observing the action they were actually more enslaved in spirit than those involved in it. Still others, looking off at some evenly fought sector of the sea battle, were kept in the most painful state of all on account of the continued uncertainty of the conflict, the intensity of their fear making their very bodies sway back and forth to match their perceptions; for all the while they were either just on the point of getting away or just on the point of being lost. And all within the Athenian army, as long as the battle on the sea was about even, you could hear everything at the same time, lamentation, shouting, "we're winning," "we're losing," every other possible outcry that would be wrung from a great army in great danger. The men on the ships were reacting in much the same way but only up until the Syracusans and their allies, after prolonged fighting, routed the Athenians and in a decisive offensive, with much shouting and cheering, drove them to the land. (Lattimore 397, 7.71.1-5)

This description is remarkable, especially in an author known for his narrative economy: it does not add anything noteworthy to the preceding account of the battle, but offers a rehash through the lens of an internal audience. The mixed responses of the Athenians on land correspond to the confusing course of the fighting reported before. The 
repetition is highlighted by references to noise and shouts that cap both descriptions (7.70.77.71.4). Thucydides devotes a noteworthy amount of narrative space and rhetorical fervor to mere bystanders, a fact that is offset by the snappy rendering of the decision and outcome of the battle (7.71.5). While the description of the spectators and their response takes up nearly a full page in the OCT edition, the routing of the Athenians is banned to a contact clause. Historians are inclined to consider Thucydides as a model for the virtue of sticking to the bare facts. The Syracusan harbor scene speaks loudly against such a view, as it illustrates a keen interest in the mind and consciousness of historical protagonists. ${ }^{12}$ The pivotal event of the Sicilian expedition, itself a key factor in Athens's downfall, is trenchantly presented as a collective experience.

The collective experience of the spectators encompasses cognition, perception and emotions: the awareness that their fate is at stake raises the involvement of the spectators. Besides vision, the obvious sense in this case, Thucydides emphasizes the acoustic perception of the battle. He distinguishes three different reactions, namely joy, pain, and insecurity. The responses of the spectators depend on what part of the battle they are currently observing. The collective experience is thus not uniform; we rather have something like a manifold collective experience.

Thucydides takes pains to drive home the intensity of the response of the internal recipients. The response is not only perceptual, emotional and cognitive, but also physical: "their bodies sway ... to match their perceptions" (7.71.3). Thucydides even states that "by observing the action they were actually more enslaved in spirit than those involved in it" (7.71.3). The tables seem to be turned between active and passive participants when the description of the spectators closes with the remark that "the men on the ships suffered in similar ways to them ..." (7.71.5). The separation of spectators and actors is actually 
discarded when the Athenian ships are beaten back and try to reach the land: both army and navy now desperately try to escape from the Syracusans who chase them.

The boundary between passive and active participants in the battle is also subtly challenged at the lexical level. "Love of victory" (filonikia) takes hold of the fighting soldiers and spectators, both from Athens and Syracuse (7.70.7; 7.71.1). More poignantly, not only the troops on the boats engage in an agōn (7.69.2; 7.70.3: agōnismos), but also the crowd at land: "And on the shore, as long as the sea battle stayed evenly balanced, the land forces on both sides experienced intense struggles (agōna) and conflict (xustasin) in their minds ..." (7.71.1). The use of the same word for the fighting and its perception eradicates the line between spectators and actors. Besides agōn, the word xustasis is pertinent to my interpretation: it is also used for combat and thereby further infuses the reception of the beholders with a military note. ${ }^{13}$ The word "enslave" forcefully expresses the grip of the battle on the spectators; through its literal meaning it gestures towards the fate that awaits the Athenian soldiers on land and sea alike.

The masterfulness of the Syracusan harbor scene did not go unnoticed in antiquity. Dionysius, writing in the second half of the first century BCE, quotes more or less the full text as illustration of "the man's sublimity of diction and his elegance of language" (de Thuc. 26-7). Roughly a century later, Plutarch extols the vividness of Thucydides's writing: "Assuredly Thucydides is always striving for this vividness in his writing, since it is his desire to make the reader a spectator, as it were, and to produce vividly in the minds of those who peruse his narrative the emotions of amazement and consternation which were experienced by those who beheld them" (de glor. Ath. 347a). To illustrate his claim, Plutarch quotes from the report of the Syracusan harbor battle. It is not incidental that the passages cited stem from the description of the soldiers following the battle from the land. The internal spectators are crucial to "making the reader a spectator." Prefiguring the reception of the 
reader, the embedded audience lets the reader see the action through the lens of an eyewitness. The emotions of the bystanders become the filter through which the reader accesses the scene.

As intuited by Plutarch, himself a master of vivid narrative, the embedded audience and its close alignment with the protagonists of the action are crucial to the spell of the Syracusan harbor scene over Thucydides's readers. Seeing the action through the eyes of observers that are fully immersed, the reader herself is jolted into the action. Besides the explicit presentation of the spectators' consciousness, style, content, and verbal tense contribute to the internal focalization of the scene. Rather than simply reporting the course of events, Thucydides casts the action as collective experience and thereby renders his narrative itself highly experiential to the reader.

Besides helping to immerse the reader in the action, the elaboration on the response of the internal audience also serves what William Labov has called the "evaluation": "the means used by the narrator to indicate the point of the narrative, its raison d'être" (366). ${ }^{14}$ As noted above, the description of the bystanders and their feelings is not relevant to the narration of the course of the battle; it even suspends the action. And yet, it highlights the significance of the battle. The excitement and anxiety of the internal audience alerts the reader to the importance of the event that is being narrated. The "embedded evaluation" permits Thucydides to indicate what is at stake without giving up his narratorial reticence. There is in general a strong interest in the minds of his characters in the History of the Peloponnesian War. While many Spartan enterprises are presented through the filter of the ingenious king Brasidas, the perspective of Nicias, the Athenian general, is prominent in the account of the Sicilian expedition. Pivotal events, however, such as the debate about the expedition, the departure of the fleet and the defeat in the Syracusan harbor tend to be foregrounded through their presentation as a collective experience. 
As this discussion shows, Thucydides does not describe social minds for their own sake. The presentation of consciousness processes is closely bound up with the narration of the action. The distinction of three different groups among the spectators, for example, one feeling joy, the other pain, and the third wavering, is not owed to an interest in different psychological makeups. Instead it is related to the action and serves to drive home the uncertainty of the outcome of the battle. Thucydides adopts the viewpoint of characters in order to put the reader in the thick of the action. History is always narrated in retrospect, and yet the passage discussed here illustrates how narrative time can be made to evoke the openness of narrated time.

Thucydides is not the only ancient historian to use collective experience as a means of immersing his audience in the past. Polybius is fond of concentric rings of reception that close the gap between action and reader (Davidson). Ab urbe condita, Livy's monumental account of Rome's history, teems with spectacle scenes featuring internal audiences (Feldherr). In Tacitus, the rumors that permeate Rome under the Emperors destabilize the historian's account and expose the reader to the insecurity felt by contemporaries (Grethlein, Experience and Teleology 140-167). The differences between these and other authors notwithstanding, the presentation of collective experience is a powerful tool in the hands of ancient historians, who are keen to restore presence to the past.

\section{Heliodorus: In the Shoes of Theagenes at Delphi}

My second test-case stems from a fictional ancient narrative, Heliodorus's novel Aithiopica. Written probably in the 3rd or 4th century CE, the Aithiopica follow the pattern that underlies all fully preserved ancient romances: a young couple, here named Charicleia and Theagenes, falls in love, but can be married only after a host of adventures and ordeals. Heliodorus artfully entwines multiple plot strands and offers a dazzling play with narrative 
and narrated time: while it takes the reader the first half of the novel to understand the prehistory and initial scene, the suspense created in the second half sends the reader on a rollercoaster. The Aithiopica's strong self-referential dimension has appealed to critics in the last decades. ${ }^{15}$ In particular, the long embedded narrative in which the Egyptian priest Calasiris reveals the bulk of the prehistory can be read as a reflection on narrative. Likewise, the audience of Calasiris's narration, an Athenian named Cnemon, sheds light on how we respond to the Aithiopica and other narratives. ${ }^{16}$

The passage that I wish to discuss stems from Calasiris's narrative. The hero-couple, Charicleia and Theagenes, meets at Delphi, where she is brought up by a foster father and where he comes as leader of a procession. They have already fallen for each other, albeit without confessing their love, when Theagenes takes on a prize-winning athlete in a footrace. The account of the race deploys the spectators in a similar way as Thucydides's Syracusan harbor scene to bring the reader close to the action. At the same time, the embedded narrator adds complexity to the relationship between spectators and readers: The whole of Greece thrilled with emotion at this dramatic turn of events and prayed for Theagenes to win as fervently as if each man were himself competing (agōnizomenos); for nothing wins the sympathy of beholders like beauty. Charicleia's emotion passed all bounds; I had been observing her carefully for some while and I saw every conceivable expression pass in succession over her face. The herald proclaimed the names of those entered for the race for all to hear, "Ormenos of Arcadia and Theagenes of Thessaly." The starting gate opened, and they were off, running at such a speed that the eye could barely keep pace. Now the maiden could not stay still; her feet began to skip and dance, as if, in my estimation, her soul were flying together (sunexairomeness) with Theagenes and sharing his passion for the race 
Narrative Time and Collective Experience in Ancient Greek Narrative

(sumprothumoumeness). The viewers were all buoyed up, anticipating the outcome, and full of agony (agōnias); I myself even more so, now that I had decided to care for Theagenes in the future as for a son. "It is not surprising," said Cnemon, "that those who were there watching were in agony (agōnian). Even now I fear for Theagenes and beg you to make haste and tell me whether he was proclaimed victor." ${ }^{, 17}(4.3 .2-4.3 .4)$

As to be expected, Theagenes comes in first. Like the battle in the Syracusan harbor, the race is reported in part as the collective experience of spectators. While Thucydides lists a range of responses without assigning them to distinct groups, Heliodorus carefully differentiates the audience in the stadium. All cheer for Theagenes, but for distinct reasons and with different intensity. The crowd is entranced by his beauty. Like Thucydides, Heliodorus stresses their immersion through the repeated use of the stem agonn (agōnizomenos, agōnias, agōnian). Besides making the involvement of the audience explicit, the agōnia felt by the spectators aligns the reception with its object and blurs the boundary between competing and watching. Of course, it is the runners who will decide the agonn, but the agonia of the audience drives home that they feel as if they were competing themselves.

Calasiris's feelings are even stronger due to his concern for the runner. Nonetheless, he can still notice the involvement of Charicleia, which is the most intense. The double use of compound verbs with the prefix sun linguistically expresses her bond with Theagenes (sunexairomenēs, sumprothumoumenēs). Charicleia's immersion in his current situation goes so far that she starts moving her feet and thereby mimics his running. Her involvement thus has a physical dimension similar to the response of the spectators of the Syracusan harbor battle whose "bodies sway to match their perceptions" (7.71.3). The graded absorption in the race drives home that the intensity of the response is calibrated by the relation of the recipient to the protagonists. 
In addition to canvassing a range of responses, Heliodorus nests multiple audiences into each other and combines various media: we read about Cnemon listening to an account of the crowd seeing the scene. The concentric circles of reception bridge the gap between reader and action, bringing her closer to the foot-race. Cnemon prefigures the reader in the framing narrative. Through his ears, the reader follows Calasiris's account that puts internal and external audience into the shoes of the spectators present. Cnemon's comment drives home that, the different forms of mediation notwithstanding, the spell of the narrative passes through the circles of receptions. The fact that the internal listener is as affected as the viewers invites the external listener or reader to be equally enticed by the account.

That being said, the response of the reader does not directly map onto the reactions of Cnemon and the spectators. Cnemon is so absorbed by Calasiris's narration that he begs him to hurry with his recital. While expressing Cnemon's absorption, this intervention reminds the reader forcefully of the narrative framing: she does not directly witness the footrace, but attends to an account embedded in a narrative. Thus, instead of prefiguring the reader's response, Cnemon's absorption and its expression draw her attention to the mediation. In another way, though, Cnemon's interruption may contribute to the spell the text casts on the reader. Retarding the narration, Cnemon's intervention heightens suspense and thereby helps to bind the reader into the story. As this passage illustrates, the responses of internal and external audiences do not necessarily converge, but grind in multiple ways against each other. $^{18}$

This qualification notwithstanding, in Heliodorus and the other ancient novelists, the deployment of embedded spectators is an important means of enticing the reader. ${ }^{19}$ It bears repeating that the portrayal of consciousness processes is not an end in itself. Unlike Thucydides, Heliodorus carefully distinguishes the responses of different spectators, and yet the enticement of the reader hinges less on the process of mind-reading than on the suspense 
created by the action. The response of the internal audience underscores how important the race is. In highlighting the significance of the event reported, it serves the purposes of "evaluation" in the sense of Labov. Moreover, the portrayal of the embedded audience helps to make the action experiential. Following the action viewed through the perceptual, cognitive, and emotional filter of an internal audience, the reader is pulled into the flux of narrated time. An approach that defines narrative as "the description of fictional mental functioning" fails to do justice to this dynamics. Heliodorus's reader is indeed invited to engage with the minds of characters. However, the presentation of consciousness is not the goal of Heliodorus's narration: it is a vehicle for rendering an action experiential.

\section{Narrative time and social minds}

It is now time to return to my initial remarks and to review the agenda of cognitive narrative theory in light of the texts just discussed. ${ }^{20}$ Cognitive studies is a wide umbrella that covers various approaches, and yet in the analysis of narrative, the theory of mind has emerged as a key concept. Scholars exploring narrative from a cognitive perspective tend to home in on processes of consciousness and the portrayal of character. Narrative, they argue, derives its spell from the minds of characters that the readers try to understand. Such a view, however, is hard to uphold for much ancient narrative. The ancient novel is a case in point. Recent scholarship has shown that characters in the novel are less static than has long been assumed. ${ }^{21}$ And yet it is hard to deny that in the Aithiopica as in the other ancient novels the characters are rather flat: the hero couple is of dashing beauty and outstanding virtue; its opponents are morally depraved. The mental processes unveiled are mostly straightforward calculations or clear-cut emotions. My discussion of the Delphic footrace has shown that the engagement with collective consciousness processes, while having little value in itself, serves to signal the importance of the action, which the narrator strives to make present for the 
reader. Instead of involving the reader in an intricate process of mind-reading, the narrative is crafted to make narrative time reproduce the openness of narrated time.

It has been suggested that the little care applied to the presentation of inner lives in much of ancient narrative is part of a different take on selfhood. Christopher Gill has argued that ancient conceptions of personality do not share the modern focus on subjectivity and individuality. ${ }^{22}$ Investigating various genres of ancient literature, Gill claims that personality is rather conceived in objective terms such as the participation in communities. No matter whether or not we link the rudimentary character portrayal in the Greek novel to Gill's claim about ancient concepts of selfhood, it is undeniably not the interest in characters and their inner lives that drives the ancient novel.

The term of agōnia which we encountered in both Thucydides and Heliodorus gestures towards a more salient point. Agōnia bridges not only the gap between action and internal spectators, but also the wider chasm that separates the reader from the world of the narrative. In an Imperial treatise on style transmitted under the name of Demetrius of Phalerum, we find a remarkable discussion of enargeia, the terminus technicus for narrative vividness: "One should not say right away what has happened, but unfold it gradually, thus keeping the reader hanging up (kremonta) and forcing him to share the anxiety (sunagōnian)" (216). While most ancient commentators on enargeia zero in on the visual appeal of words, Demetrius here elaborates on what we call suspense. ${ }^{23}$ Suspense, he notices, endows narrative with vividness by making the reader share the anxiety of the characters. ${ }^{24}$

The suspense felt by the reader is admittedly different from the suspense to which the narrative characters are subjected. The reader of the History of the Peloponnesian War knows that the Athenian fleet will be wrecked just as the hero in a novel can be firmly expected to come first in a race. And yet, psychologists and literary scholars have made clear that stories can be suspenseful even if their ending is known. ${ }^{25}$ The reader's attention can be leveled at 
how the known outcome will be brought about. Suspense can also proliferate from the tension between the reader's desire and knowledge. As an expert reader of Thucydides puts it: "Whenever I re-read Book VII of Thucydides I keep hoping it'll go the other way this time" (Green xii).

Suspense is a temporal phenomenon that is linked to the sequential form of narrative. We are eager to see the plot unfold and come to an end. Suspense is however only one effect of the narrative orchestration of time, as the Aithiopica illustrate. During the first books, the reader is not only wondering about the further course of events, but also curious to learn more about the prehistory. Besides suspense and curiosity, the former directed to the future, the latter to the past, surprise is a further important aspect of the narrative reconfiguration of time. Here an unexpected twist is based on an antecedent of which the reader was unaware. In his neo-Aristotelian approach to narrative, Sternberg goes so far as to "define narrativity as the play of suspense/curiosity/surprise between represented and communicative time (in whatever combination, whatever medium, whatever manifest or latent form" (“Telling in Time (II)" 529). ${ }^{26}$

Cognitive studies in narrative do not ignore narrative time, ${ }^{27}$ but are in danger of underestimating it. Palmer himself comments knowingly on narrative time and introduces the intriguing concept of "thought-action continuum," but the very few pages he devotes to it illustrate that his major interest lies with mind-reading (Fictional Minds 212-214). ${ }^{28}$ It is, I suspect, the focus on the classical modern novel that has led to privileging the representation of consciousness. Authors such as Austen, Woolf, and James are highly invested in the inner lives of their characters. ${ }^{29}$ Eliot's Middlemarch is a strong case in point for the pervasiveness of social minds for which Palmer argues. That being said, it is important to acknowledge that even these novels go beyond a pure "description of fictional mental functioning" (Fictional 12). They show the workings of narrative minds as part of a temporal sequence. Thoughts, 
feelings, and conjectures are not presented for their own sake, but figure in a plot, minimal as it may be. While putting much emphasis on processes of consciousness, the classical modern novel embeds the portrayal of inner lives of characters in narrated time. Even experimental works that aspire to spatial form are still bound to the sequential form of narrative. ${ }^{30}$ Note also that the modern period harbors narrative genres that thrive on narrative time as does the ancient Greek novel. The roman policier, for example, and other genres of paralittérature tend to treat characters rudimentarily and instead capitalize on the dynamics of plot. ${ }^{31}$ I do not risk much when I claim that these works enjoy a broader readership than the classical modern novel and experimental narratives taken together. Narrative provides not only a safe training ground for the theory of mind, it also lets us engage with time in a playful way. ${ }^{32}$

Let me emphasize that I do not wish to play narrative time against character portrayal. Both are entangled with each other. Pure "description of fictional mental functioning" will hardly entice readers. Novels like Hermann Broch's The Death of Virgil are experiments that, in reducing the action to a minimum, put the patience of readers to the test. It is the intentions and goals of characters and how they turn out in the action that instill life into stories. Conversely, plot without introspection is in danger of being anemic. Even narratives that avoid revealing the inner lives of characters provoke the reader into inferring their feelings and motives. Reading such stories as Hemingway's The Killers we constantly make conjectures about the minds of the characters. Sternberg is right to point out the salience of the tension between narrative and narrated time, but it is important to heed that the duplication of time comes in tandem with a duplication of consciousness. Just as the sequence of reading is grafted onto the sequence of the action, the consciousness of the reader attends to the consciousness of the characters. Narrative invites us to engage with the minds of characters in narrative time and to follow the unfolding of narrated time through their lens. 
It should be clear by now why I have spoken rather of collective experience than of social minds. ${ }^{33}$ An exploration of social minds, as advocated by Palmer, can of course take into account the temporal dimension of narrative, but the notion of experience seems better suited to conceptualize the salience of time to narrative. While the notion of mind can be static, the idea of experience is inherently dynamic. Hans-Georg Gadamer in particular has emphasized the temporal character of experiences (352-68). We have an experience when our consciousness undergoes a reversal: "If a new experience of an object occurs to us, this means that hitherto we have not seen the thing correctly and now know it better" (347). ${ }^{34}$ Experiences are not only temporal, they also make us sense time: “ . . experience is experience of human finitude" (351). ${ }^{35}$

The concept of experience is also capable of covering the level of reading as well as that of narrative action. The temporal character of narrative makes reading itself a form of experience; the reader re-experiences the experiences of characters. ${ }^{36}$ Needless to say, reading experiences are only indirect — while the characters of a novel are tortured or killed, we sit comfortably in our favorite easy chair. And yet, ancient critics such as Plutarch highlight the intensity that reading experiences can acquire. ${ }^{37}$ Take, for example, Gorgias who comments on the power of words: "In those who hear it comes fearful fright and tearful pity and mournful longing, and at the successes and failures of others' affairs and bodies the mind suffers, through the words, a suffering of its own" (11.9 DK). Collective experience in particular is a powerful tool for rendering narrative experiential. As the examples from Thucydides and Heliodorus have shown, the focus on collective experience makes the reader follow the action through the lens of eyewitnesses and brings her close to the scene.

\footnotetext{
${ }^{1}$ I wish to thank Eva von Contzen, Maximilian Alders and especially Jim Phelan for helpful comments and suggestions. The work on this essay has been funded by the European Research Council (Grant Agreement n. 312321).
} 
${ }^{2}$ Medieval narrative poses similar problems to Palmer's theory of social minds; see von Contzen (this volume).

${ }^{3}$ In the Poetics, Aristotle ranks plot (mythos) higher than character (ethos). Sternberg's two essays on "Telling in Time" as well as Baroni's La tension narrative and "Regarder le monde en face?" are important proponents of the Neo-Aristotelian tradition. Ricoeur's Temps et récit is still the essential treatment of time and narrative from a phenomenological perspective. For an attempt to refine Ricoeur's approach with a more detailed literary analysis, see Grethlein's "The Narrative Reconfiguration of Time beyond Ricoeur."

${ }^{4}$ For a survey of scholarly approaches to the "invention of fiction" in antiquity, see Tim Whitmarsh's Beyond the Second Sophistic (11-12).

${ }^{5}$ For the impact of ancient historiography on the ancient novel, see Morgan's "History, Romance, and Realism” and Elmer's “Heliodoros's 'Sources'.”

${ }^{6}$ My treatment of the Syracusan harbor scene is confined to the presentation of collective experience. Other important aspects include echoes of the departure of the fleet from Piraeus (6.30-31) and the correspondence with Pylos that is explicitly pointed out by Thucydides in 7.71.7. On the Syracusan harbor scene in general, see Rutter's Companion and Rood's Thucydides: Narrative and Explanation (159-82).

${ }^{7}$ Despite recent work on Thucydides's literary techniques, the image of an objective historian still remains prominent. See for example Kagan, who asserts that Thucydides wrote history, "aiming at the highest possible objectivity, clinging assiduously to his subject, and avoiding tangents almost entirely" (8).

${ }^{8}$ The translations of Thucydides are taken from Lattimore's Thucydides with my modifications; while perhaps less elegant, these convey better the literal meaning of the Greek. 
${ }^{9}$ See Rijksbaron, who observes that, in a wide range of Ancient Greek texts, the imperfect is used in combination with "substitutionary perception"- the substitution of a character's perception for that of the author-and argues, "since these tenses (i.e. the imperfect in Greek, the French imparfait and the past progressive in English) denote durative, ongoing states of affairs they can be 'hit' by the gaze of some character, if he happens to be present in the narrative at that particular point" (373).

${ }^{10}$ See also Bakker's Pointing at the Past (154-76) and "Time, Tense and Thucydides." While indebted to Bakker's analysis of the mimetic use of the imperfect in Thucydides, I part company with him when he claims that we need new categories to grasp this function of the imperfect. As noted above, the denotation of duration suffices to explain the mimetic appeal of the imperfect. See also Colvin, "Grammar as Interpretation."

${ }^{11}$ On the experiential quality of Thucydides's narrative, see Grethlein's “Experientiality and Narrative Reference" and Experience and Teleology in Ancient Historiography (29-51).

${ }^{12}$ On Thucydides's interest in the minds of the historical actors, see especially Hunter's Thucydides. The Artful Reporter.

${ }^{13}$ Cf. Herodotus, The Histories 6.117.2. For a defense of the transmitted text, see Gomme, Andrewes, and Dover ad 7.71.1.

${ }^{14}$ See also Labov and Waletzky.

${ }^{15}$ See the seminal paper by Winkler and the contributions to Hunter's Studies in Heliodorus.

${ }^{16}$ On embedded audiences in the Aithiopica, see besides Winkler also Morgan, "Reader and Audiences.”

${ }^{17}$ The translations of Heliodorus are taken, with modifications, from Morgan's "Heliodorus: An Ethiopian Story.”

${ }^{18}$ See also Grethlein, “Aesthetic Experiences, Ancient and Modern,” forthcoming in New Literary History. 
${ }^{19}$ See for example the analysis of embedded audiences in Chariton by Kaimio.

${ }^{20}$ I develop this point at more length in a paper forthcoming in Style, which critically reviews the application of the theory of mind in narrative studies.

${ }^{21}$ Konstan; Jones; de Temmermann.

${ }^{22}$ Other scholars, however, are eager to show that most facets of modern selfhood are already present in antiquity. See, for example, the contributions to Arweiler and Möller's collection. ${ }^{23}$ There is no terminus technicus for suspense in ancient criticism. Besides "being in agony," metaphors such as "hanging up," "setting aflutter" and "to leave the spur in the readers" (Scholion bT Il. 85a, quoting Eupolis fr. 102.7 K.-A.) render its effect on the reader vividly. ${ }^{24}$ For similar observations, see Ps.-Plut. Hom. 6 and Scholion bT Il. 7.479: "The poet rouses the reader beforehand and makes him feel anxious (agōnian) in view of the future events." Cf. Nannini (41-9).

${ }^{25}$ See Baroni’s La tension narrative, 269-95, for a survey.

${ }^{26}$ From a philosophical perspective, the pertinence of time to narrative has been flagged by Ricoeur in Temps et récit.

${ }^{27}$ See, for example, the chapters on time in Ryan and Herman.

${ }^{28}$ See also Social Minds in the Novel, 135.

${ }^{29}$ See, before the cognitive turn, Dorrit Cohn's Transparent Minds (1978).

${ }^{30}$ The classical treatment of spatial narrative is Frank's 1945 “Spatial Form in Modern Literature," re-published with more material in 1991 as The Idea of Spatial Form.

${ }^{31}$ See, for example, Couégnas. For an instructive comparison of the ancient novel with paralittérature, see Fusillo.

${ }^{32}$ For this argument, see also my "Is Narrative "the Description of Mental Functioning"”.

${ }^{33}$ Fludernik's Towards a 'Natural' Narratology remains the landmark study on narrative and experience. 
34 "Wenn wir an einem Gegenstand eine Erfahrung machen, so heißt das, daß wir die Dinge bisher nicht richtig gesehen haben und nun besser wissen, wie es damit steht” (359).

35 "Erfahrung ist also Erfahrung der menschlichen Endlichkeit” (363).

${ }^{36}$ See also my "Experientiality and Narrative Reference" and Experience and Teleology in Ancient Historiography.

${ }^{37}$ On the ancient emphasis on strong responses to narrative as well as art and its relevance to current aesthetics, see my forthcoming article in New Literary History, "Aesthetic Experiences, Ancient and Modern." 
Narrative Time and Collective Experience in Ancient Greek Narrative

\section{Works Cited}

Aristoteles. De arte poetica liber, edited by Rudolf Kassel. Oxford: Oxford Univ. Press, 1965.

Arweiler, Alexander and Melanie Möller, eds. Vom Selbst-Verständnis in Antike und Neuzeit. Berlin: de Gruyter, 2008.

Bakker, Egbert J. Pointing at the Past. From Formula to Performance in Homeric Poetics. Cambridge, MA: Harvard Univ. Press, 2005.

__. "Time, Tense, and Thucydides." Classical World 100.2 (2007): 113-22.

—_. "Verbal Aspect and Mimetic Description in Thucydides." In Grammar as Interpretation: Greek Literature in Its Linguistic Contexts, edited by Egbert J. Bakker, 7-54. Leiden: Brill, 1997.

Baroni, Raphaël. La tension narrative: Suspense, curiosité et surprise. Paris: Seuil, 2007.

—_. "Regarder le monde en face?” In L'oeuvre du temps. Poétique de la discordance du temps, edited by Raphaël Baroni, 167-200. Paris: Seuil, 2009.

Broch, Hermann. Der Tod des Vergil. Zurich: Rhein-Verlag, 1947.

Cohn, Dorrit. The Distinction of Fiction. Baltimore: John Hopkins Univ. Press, 1999.

—. Transparent Minds: Narrative Models for Presenting Consciousness in Fiction. Princeton: Princeton Univ. Press, 1978.

Colvin, Stephen. "Review E. Bakker (ed.), Grammar as Interpretation: Greek Literature in its Linguistic Contexts, 1997.” Bryn Mawr Classical Review 10.03 (1998): n. pag.

Couégnas, Daniel. Introduction à la paralittérature. Paris: Seuil, 1992.

Davidson, James. "The Gaze in Polybius' Histories." The Journal of Roman Studies 81 (1991): 10-24.

Demetrius. On Style, edited by W. Rhys Robert. Cambridge: Cambridge Univ. Press, 1902.

Diels, Hermann and Walther Krantz, eds. Die Fragmente der Vorsokratiker, I-III. 6th ed. 
Narrative Time and Collective Experience in Ancient Greek Narrative

Berlin: Weidmann, 1952.

Dionysius Halicarnassensis. Opuscula, edited by H. Usener and L. Radermacher. Leipzig: Teubner, 1899.

Elmer, David F. 'Heliodoros's 'Sources': Intertextuality, Paternity, and the Nile River in the 'Aithiopika'." Transactions of the American Philological Association 138.2 (2008): 411-50.

Erbse, H. Scholia Graeca in Homeri Iliadem. I-VII. Berlin: de Gruyter, 1969-1988.

Feldherr, Andrew. Spectacle and Society in Livy's History. Berkeley: Univ. of California Press, 1998.

Ferguson, William Scott. “The Athenian Expedition to Sicily.” In Cambridge Ancient History V: Athens 478-401 B.C., edited by J. B. Bury, S. A. Cook, and F. E. Adcock, 282-311. Cambridge: Cambridge Univ. Press, 1935.

Fludernik, Monika. “The Diachronization of Narratology.” Narrative 11.3 (2003): 331-48.

—. Towards a 'Natural' Narratology. London: Routledge, 1996.

Frank, Joseph. The Idea of Spatial Form. New Brunswick: Rutgers Univ. Press, 1991.

__. "Spatial Form in Modern Literature: An Essay in Two Parts." The Sewanee Review 53.2 (1945): 221-40.

Fusillo, Massimo. "Il romanzo antico come paraletteratura? Il topos del racconto di ricapitolazione.” In La letteratura di consumo nel mondo greco-latino, edited by Oronzo Pecere and Antonio Stramaglia, 47-67. Cassino: Università degli studi di Cassino, 1996.

Gadamer, Hans-Georg. Truth and Method. Translated by Joel Weinsheimer. New York: Continuum, 2004.

—. Wahrheit und Methode: Grundzüge einer philosophischen Hermeneutik. 1960. Tübingen: Mohr, 1990. 
Narrative Time and Collective Experience in Ancient Greek Narrative

Gill, Christopher. Personality in Greek Epic, Tragedy, and Philosophy: The Self in Dialogue. Oxford: Clarendon Press, 1996.

Gomme, Arnold W., Anthony Andrewes, and Kenneth James Dover. A Historical Commentary on Thucydides I-V. Oxford: Clarendon Press, 1945-1981.

Green, Peter. Armada from Athens. New York: Doubleday, 1970.

Grethlein, Jonas. “Aesthetic Experiences, Ancient and Modern.” New Literary History (forthcoming).

—. Experience and Teleology in Ancient Historiography: 'Futures Past' from Herodotus to Augustine. Cambridge: Cambridge Univ. Press, 2013.

__ 'Experientiality and 'Narrative Reference,' With Thanks to Thucydides.” History and Theory 49.3 (2010): 315-35.

—_. "Is Narrative 'the Description of Mental Functioning'? Heliodorus against Palmer, Zunshine and Co." Style (forthcoming).

__ "The Narrative Reconfiguration of Time beyond Ricœur." Poetics Today 31 (2010): 313-29.

Herman, David. Story Logic: Problems and Possibilities of Narrative. Lincoln: Univ. of Nebraska Press, 2002.

Homer. Opera V, edited by T. W. Allen. Oxford: Oxford Univ. Press, 1912.

Hunter, Richard L., ed. Studies in Heliodorus. Cambridge: Cambridge Philological Society, 1998.

Hunter, Virginia J. Thucydides, the Artful Reporter. Toronto: Hakkert, 1973.

Jones, Meriel. Playing the Man: Performing Masculinities in the Ancient Greek Novel. Oxford: Oxford Univ. Press, 2012.

Kaimio, Maarit. "How to Enjoy a Greek Novel: Chariton Guiding His Audience." Arctos 30 (1996): 49-73. 
Kagan, Donald. Thucydides: The Reinvention of History. New York: Viking, 2009.

Konstan, David. Sexual Symmetry: Love in the Ancient Novel and Related Genres. Princeton: Princeton Univ. Press, 1994.

Labov, William. Language in the Inner City: Studies in the Black English Vernacular. Philadelphia: Univ. of Pennsylvania Press, 1972.

Labov, William and Joshua Waletzky. "Oral Versions of Personal Experience.” In Essays on the Verbal and Visual Arts, edited by June Helm, 12-45. Seattle: Univ. of Washington Press, 1967.

Lattimore, Steven. Thucydides: The Peloponnesian War. Indianapolis: Hackett, 1998.

Morgan, J. R. "Heliodorus: An Ethiopian Story.” Translated by J. R. Morgan. In Collected Ancient Greek Novels, edited by Bryan P. Reardon, 349-588. Berkeley: Univ. of California Press, 2008.

Morgan, John R. "History, Romance, and Realism in the Aithiopika of Heliodorus." Classical Antiquity 1.2 (1982): 221-65.

—. "Reader and Audiences in the Aithiopika of Heliodorus." In Groningen Colloquia on the Novel IV, edited by Heinz Hofmann and Maike Zimmermann, 85-103. Groningen: Egbert Forsten, 1991.

Nannini, Simonetta. Omero e il suo pubblico nel pensiero dei commentatori antichi. Rome: Edizione dell'Ateneo, 1986.

Palmer, Alan. Fictional Minds. Lincoln: Univ. of Nebraska Press, 2004.

_. Social Minds in the Novel. Columbus: Ohio State Univ. Press, 2010.

Plutarch. Moralia VI. Translated by F. C. Babbitt. Cambridge, MA: Harvard Univ. Press, 1936.

Ricoeur, Paul. Temps et récit. I-III. Paris: Seuil, 1983-1985.

Rijksbaron, Albert. “The Imperfect as the Tense of Substitutionary Perception.” In 
Narrative Time and Collective Experience in Ancient Greek Narrative

Hyperboreans: Essays in Greek and Latin Poetry, Philosophy, Rhetoric and Linguistics, edited by Paula da Cunha Corrêa, Marcos Martinho, and Alexandre Pinheiro Hasegawa. Sao Paulo: Humanitas, 2012.

Rood, Tim. Thucydides: Narrative and Explanation. Oxford: Oxford Univ. Press, 1998.

Rutter, N. Keith. Thucydides VI and VII: A Companion to the Penguin Translation of Rex Warner. Bristol: Bristol Classical Press, 1989.

Ryan, Marie-Laure. Narrative as Virtual Reality: Immersion and Interactivity in Literature and Electronic Media. Baltimore: Johns Hopkins Univ. Press, 2001.

Smyth, Herbert Weir and Gordon M Messing. Greek Grammar. Cambridge, MA: Harvard Univ. Press, 1984.

Sternberg, Meir. “Telling in Time (I).” Poetics Today 11.4 (1990): 901-48.

—_. "Telling in Time (II).” Poetics Today 13.3 (1992): 463-541.

De Temmerman, Koen. Crafting Characters: Heroes and Heroines in the Ancient Greek Novel. Oxford: Oxford Univ. Press, 2014.

Whitmarsh, Tim. Beyond the Second Sophistic: Adventures in Greek Postclassicism. Berkeley: Univ. of California Press, 2013.

Winkler, John J. "The Mendacity of Kalasiris and the Narrative Strategy of Heliodorus' Aithiopika." In Yale Classical Studies: 27, edited by John J. Winkler and Gordon W Williams, 93-158. Cambridge: Cambridge Univ. Press, 1982.

Zunshine, Lisa. Why We Read Fiction: Theory of Mind and the Novel. Columbus: Ohio State Univ. Press, 2006. 